\title{
"Municipal bonds as a tool for financing capital investment in local government units in Palestine"
}

\begin{tabular}{|c|c|}
\hline & Khaled Zedan iD https://orcid.org/0000-0001-9904-6313 \\
\hline AUTHORS & $\begin{array}{l}\text { Ghassan Daas } \\
\text { Yaqin Awad }\end{array}$ \\
\hline ARTICLE INFO & $\begin{array}{l}\text { Khaled Zedan, Ghassan Daas and Yaqin Awad (2020). Municipal bonds as a } \\
\text { tool for financing capital investment in local government units in Palestine. } \\
\text { Investment Management and Financial Innovations, 17(1), 213-226. } \\
\text { doi:10.21511/imfi.17(1).2020.19 }\end{array}$ \\
\hline DOI & http://dx.doi.org/10.21511/imfi.17(1).2020.19 \\
\hline RELEASED ON & Thursday, 26 March 2020 \\
\hline RECEIVED ON & Wednesday, 04 December 2019 \\
\hline \multirow[t]{2}{*}{ ACCEPTED ON } & Friday, 06 March 2020 \\
\hline & $(\mathrm{cc})$ EY \\
\hline LICENSE & $\begin{array}{l}\text { This work is licensed under a Creative Commons Attribution } 4.0 \text { International } \\
\text { License }\end{array}$ \\
\hline JOURNAL & "Investment Management and Financial Innovations" \\
\hline ISSN PRINT & $1810-4967$ \\
\hline ISSN ONLINE & $1812-9358$ \\
\hline PUBLISHER & LLC "Consulting Publishing Company "Business Perspectives" \\
\hline FOUNDER & LLC "Consulting Publishing Company "Business Perspectives" \\
\hline
\end{tabular}

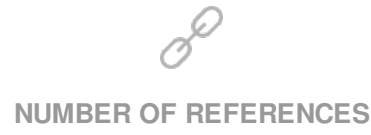

25
NUMBER OF FIGURES

0
NUMBER OF TABLES

15

(C) The author(s) 2022. This publication is an open access article. 


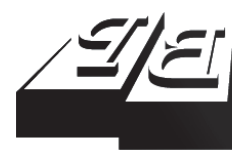

BUSINESS PERSPECTIVES

(O)

LLC "CPC "Business Perspectives" Hryhorii Skovoroda lane, 10, Sumy, 40022, Ukraine www.businessperspectives.org

Received on: $4^{\text {th }}$ of December, 2019 Accepted on: $6^{\text {th }}$ of March, 2020 Published on: $26^{\text {th }}$ of March, 2020

(c) Khaled Zedan, Ghassan Daas, Yaqin Awwad, 2020

Khaled Zedan, Ph.D. in Finance, An-Najah National University, Nablus, Palestine. (Corresponding author)

Ghassan Daas, Ph.D. in Accounting, An-Najah National University, Nablus, Palestine.

Yaqin Awwad, Master in Accounting, An-Najah National University, Nablus, Palestine.

\section{MUNICIPAL BONDS AS A TOOL FOR FINANCING CAPITAL INVESTMENT IN LOCAL GOVERNMENT UNITS IN PALESTINE}

\begin{abstract}
Municipal bonds are an option available to many cities to raise long-term financing to finance the infrastructure projects. This study aims to develop and find local measures of creditworthiness that are suitable and applicable for local government units in Palestine. Different variables are recognized to see the effect on the issuance of municipal bonds, macroeconomic variables measured by revenues and expenditures per capita, cost of capital, and unemployment rate. Municipal status variables have subgroup variables of municipality size, financial reporting quality, outstanding debt, and financial distress. Various financial ratios, comparative and cross-sectional analysis, horizontal and vertical analysis were used. These ratios and analysis have been used to determine the municipal status variable. The results of the study were limited to the largest 11 sample municipalities; each is the central local government unit at the governorates and was not generalized for all municipalities in Palestine. The study found that macroeconomic and municipality status affects the issuance of municipal revenue bonds. Based on the study results, municipal bonds are highly recommended. Also, instructions from the Ministry of Local Government need to be established and to enforce municipalities about the declaration date of publishing audited financial statements.
\end{abstract}

\section{Keywords}

Palestine, municipalities, revenues, grants, debt, budget, deficit, creditworthiness, municipal finance, regulations

\section{JEL Classification G14, G24}

\section{INTRODUCTION}

Municipalities are the main local government units (LGUs) in Palestine. The financial resources affect the sustainable development of local units; therefore, attention should be given to support the municipal development projects. Budget deficit due to lack of financing is the primary obstacle that is hindering the implementation of strategic plans and the improvements of local government units and municipalities.

Municipalities' budgets vary from one to another since some of the Palestinian municipalities own and operate electric and water services, while other municipalities do not. Water and electricity are providing cash to the municipalities and exaggerate the budgets.

The recent economic downturn was a painful reminder that LGUs cannot always rely on the availability of capital grants and borrowing to finance their infrastructure needs (Daniels \&Vijayakumar, 2007). Reform of the local government financing system is a prerequisite for the success of municipalities in Palestine (World Bank LGPA, 2017). Lacking financial securities in Palestine is threatening most of the LGUs. Financial securities are the most effective method for funding 
the development projects and improving the quality of the municipal services. Among the various types of securities are municipal bonds, a primary tool for optimizing revenues of municipalities (Ramazanov \& Grigorian, 2015).

Municipal bonds are issued by LGUs to fund activities that aim to serve civic duties and public goods. According to Horizon for Sustainable Development (HSD), a recommendation was given to investigate the viability of issuing municipal bonds for capital investment projects in Palestine (Horizon, 2009). Using municipal bonds requires analyzing the conditions before the issuance of municipal bonds and analyzing the effect on future investments for the LGUs in Palestine.

According to the Palestinian Capital Market Authority (PCMA), corporate bonds have been issued four times before 2018; these bondsare included in the law of financial securities. Whereas municipal bonds are not mentioned in the financial system regulation for the local government units in Palestine, a new draft of financial regulation is edited in 2017.

The purpose of this study is to review the municipal bond tactics to determine the suitable characteristics for bond issuance for the Palestinian market. Introducing municipal bonds andusing the most relevant variables toreach capital investmentfinancing, this research encourages spreading the culture of municipal bonds based on financial analysis and scientific methods to define the additional requirements of the legal framework. There are specific requirements and procedures for issuing municipal bonds, which are the subject of this study. The study examines employing municipal bonds as a tool for economic development projects of LGUs.

Meanwhile, creditworthiness of municipalities is questioned. Also, the extension in the legal framework in Palestine is still under development. This research will examine the determinants of the Palestinian municipality's bond issuing; bonds are needed to draw the road map of strategic growth in the coming decades. This research tries to answer the following main questions:

1. Do macroeconomic variables measured by revenues and expenditures per capita, cost of capital, and unemployment affect the issuance of municipal bonds?

2. Do municipal status variables affect the issuance of municipal bonds, which has subgroup variables of municipality size, financial reporting quality, outstanding debt, and financial distress?

Based on the previous questions, the study tries to determine whether municipal bonds solve the financing obstacle for development projects of the local government units in Palestine.

This study contributes to the literature as it is the first study investigating the issuing of municipal bonds as a tool for financing capital investment in local government units in Palestine.

\section{LITERATURE REVIEW AND HYPOTHESES}

Strengthening municipalities is vital because many policy choices can best be made at the local level, where local needs and preferences are articulated (ARIJ, 2009). Hence, the implementation of service delivery is left to the local level authorities because they have experience in service delivery. Issuing municipal bonds has become a popular method of financing the deficit of local budgets. The issue of bonds has not been targeted to generate revenues but to replenish the local budget (Ramazanov \& Grigorian, 2015).

The Palestinian financial municipal situation is very alarming and critical, as many municipalities cannot provide staff salaries regularly (ARIJ, 2009). The decline in budget inherited budget deficits. There is a difference between explicit and im- 
plicit budget deficits. Loans can cover the explicit deficit by cutting some expenses. This would affect the quality of local services because this cut will be from the operating and maintenance costs, although it should be from the administrative and salaries expenses. However, the main concern is the implicit budget deficit, which forces municipalities to cut investments and projects and to decrease their improvements implicitly.

LGUs consist of municipalities, village councils, and joint service councils. The primarypurpose of LGUs is to provide the services, while the purpose of companies in the private sector isprofit maximization. The goal of public entities is to provide adequate and economic services for society (Kablan, 2013). While profits do not matter to municipalities, it cannot be used as a "criterion for determining the success of a public government's management"(Angkinand, Barth, Phumiwasana, \& Wihlborg, 2010).What matters is to ensure that revenuesand expenditures are used in the most efficient ways. Most efficient use can guarantee the healthy functioning of the budget,properaccounting, and the financial control system correspondingly (Kablan, 2013). Management of expenditures efficiently leads to the elimination of any unproductive expenditures and to better understand the use of scarce public resources (World Bank LGPA, 2017).

Issuing municipal bonds has become a popular method of financing the deficit of local budgets. The issue of bonds has not been targeted to generate revenues but to replenish the local budget (Ramazanov \& Grigorian, 2015). For investors, municipal bonds remain one of the most conservative and less risky investments.

Numerous researches and studies examined the municipal bonds issue and their effect by the set of variables.

Liu, Wang and Wu (2003) examined the effects of fiscal institutions, such as tax and expenditure limitations, debt limitations and balanced budget rules, on state government bond ratings by using data from 1973 to 1995.The results suggest that laws which restrict state governments' ability to carry forward a deficit, tend to lead to higher credit ratings and lower interest costs.
Harris and Piwowar (2006) examine the average transaction costs of all US municipal bond trades over one year. The results showed that the costs of municipal bond transactions decrease with the volume of trade and do not depend significantly on trade's frequency. Besides, they found that municipal bond trading was much more expensive than similar equity trades. They attribute these results to, among other things, the lack of transparency in the bond market prices.

On the other hand, Balaguer (2001) investigated the Spanish municipality's indebtedness from 1992 to 1996 . The annual increase in indebtedness was considered, and the regression of the regular least squares was carried out step by step, including all years. The results found that capital expenditures, population, and nonfinancial surplus explain the dependent variable. At a lower significance level, the net operating balance also affected the dependent variable.

Kiewiet and Szalaky (1996) tested the determinants of public debt. For this purpose, they applied a panel data methodology, with cross-sectional data (49 US states) from 1961 to 1990 . The relevant conclusion emphasized that the individual income and the ideology of the ruling party (left-wing) had a positive impact on the level of indebtedness.

Capeci (1991) examines how local government financial policies impact the default risk premium on the cost of borrowing. By focusing on the issue of sustainability that may arise between domestic financial policy and municipal bond yields, the study approves that causality is not unidirectional, and the budget decisions influence the interest rate paid by local authorities.

Simonsen, Robbins, and Helgerson (2001) emphasize that smaller local authorities with insufficient qualified financial personnel will affect the terms of the bond issue. By testing a sample of US municipal bonds and after controlling many variables that would potentially affect returns, the study found that the size of the population in local government had a major impact on interest rates, particularly those local authorities with a population less than ten thousands of citizens pay higher interest rates. 
Benson, Kidwell, Koch, and Rogowski (1981) tested the systematic variation in municipal bonds yield spreads with a special focus on the business cycle. The study employed explanatory variables (classification, magnitude of the problem, etc.) and two business cycle indicators (the change in GDP and consumer sentiment index). The results of the study suggest that the yield margins expanded during the economic downturn and narrowed during economic expansion, with a greater impact on bonds with a lower rating than bonds with a higher rating.

Finally, Schulz and Wolff (2009) used quantitative analysis to test the yield differential between German government bonds and federal state bonds by using panel data regression model. The study found that yield differences between them were mainly driven by international risk aversion, as the yield differential avoids risk aversion in international markets between the BBB and US Government Treasury Index.

Municipal budgets in Palestine have significantly declined over the last decade due to the significant political risks, the contraction of the economy, high unemployment rate, poor municipal management, and a growing culture of non-payment liabilities by residents. The Palestinian financial municipal situation is very alarming and critical, as many municipalities cannot provide staff salaries regularly (ARIJ, 2009). The decline in budget inherited budget deficits. There is a difference between explicit and implicit budget deficits. Loans can cover the explicit deficit or by cutting some expenses. This would affect the quality of local services because this cut will be from the operating and maintenance costs, although it should be from the administrative and salaries expenses. However, the main concern is the implicit budget deficit, which forces municipalities to cut investments and projects and to decrease their improvements implicitly.

Palestine has a $3 \%$ increase in population every year (PCBS, 2012), grants were considered stable in amount for the previous years by MDLF, so there is no match between the increase in population and the need in municipal financing. The deterioration of municipal finances has led to a subsequent decline of service coverage and qual- ity, ultimately negatively impacting the quality of life of most Palestinians. Various achievements have improved the quality of services provided by municipalities. The water and wastewater services have been enhanced and developed in the last ten years. Many improvements are still in need; new water infrastructure is a top priority to reduce leakage to an acceptable level.

Municipalities are forced to limit service provisions to the basic minimum due to the economic crises. The following are some facts on service levels in Palestine:

- $26 \%$ of water supply network needs maintenance;

- $52 \%$ of municipal roads are unpaved and require maintenance;

- municipalities have only $46 \%$ of the required equipment;

- municipalities have $82 \%$ of classrooms needed.

Palestinian National Authority (PNA) has only full civil and security control over 18 percent of the West Bank (Area A) and manages public affairs in around 21 percent of the West Bank (Area B), with security under Israeli control (World Bank LGPA, 2017). The remaining 61 percent of the West Bank is Area C under full Israeli military administration. Population in Area $\mathrm{C}$ reached 279,000 (World Bank LGPA, 2017). LGUs in areas classified as B and C face additional challenges, obtaining permissions for development as to Oslo Agreement is a hurdle to development needs. Construction and maintenance in area $\mathrm{C}$ require a permit and approval from Israel this permit is extremely hard to obtain and may take years. They have less access to services and poorer quality for those available. They rely on outdated, deteriorated infrastructure, and when granted, the limited number of additions and upgrades are wholly insufficient to address Palestinian's needs (World Bank LGPA, 2017).

Another major issue facing municipalities is the increase in the total debt due to citizens (Horizon, 2009). In Palestine, the failure to pay the municipality's obligations, such as taxes, water, and electricity costs, has become a culture for many citizens, which negatively affects the municipality's liquidity and its ability to provide services to cit- 
izens. The accumulated debt on municipal residents reaches hundreds of USD million.

The culture of non-payment in Palestine is prevalent, not only by citizens who do not pay their fees and taxes but also by municipalities who do not pay their obligations of water and electricity bills, reaching to the higher level of central government, which does not pay their net expenses and the collection of property tax and transportation fees periodically. LGUs depend heavily on user fees to finance operating expenditures, not to mention critical capital investments. On average, charges and service fees account for $50-70 \%$ of total revenues, mostly from public utility services such as electricity and water, but also from charges for building permits, solid waste collection, signboards, and cemetery fees.

As a critical first step, the Ministry of Local Government must review and revise LGU revenue and expenditure assignments. These are significant shortcomings that need to beconsidered by the Ministry of Finance and Planning (MoFP). Although Palestinian municipalities and village councils are responsible for providing critical public services, they have not been assigned sufficient revenue sources. Changing the financial incentive structure for service provision will need to be at the core of the reform agenda. Due to chronic underfunding, LGUs have developed a practice of diverting revenues from service fees to meet their expenditures needs (World Bank LGPA, 2017).

Due to the delay in remitting the municipal transfers and the acute need for the funds collected, many studies have called for those municipalities to collect the tax themselves, at least to ensure the daily liquidity needs (Sawafta, 2011). To achieving transparency, the Ministry of Local Government has adopted decentralization policies with municipalities, which is a major issue to them. $90 \%$ of municipalities surveyed could collect property tax, and they refuse the current collection method due to the low collection rate of the tax and delay of transferring collected taxes.

Palestinian National Authority needs to introduce a system of conditional grants beyond the donor-funded Municipal Development Program to fund delegated responsibilities and provide an incentive for LGUs to complement and implement the Palestinian authority's sectoral objectives at the local level. These conditional grants are to be allocated by the MoLG as it is the monitor on the LGUs that receives and requires data on all municipalities in Palestine. Intergovernmental transfers are analyzed in the following table, with the variance percent between the actual and the budgeted intergovernmental revenues.

Based on the study problem and its objectives, the hypotheses can be formulated as follows:

H1: Macroeconomic variables do not affect the issuance of municipal bonds.

H2: Municipal status variables do not affect the issuance of municipal bonds.

\section{RESEARCH METHODOLOGY}

The research population includes all municipalities in Palestine, which reached 128 municipalities, according to the Palestinian Central Bureau of Statistics. The eleven largest west bank municipalities that are rated as large municipalities have been chosen for this study; Gaza strip is not covered here because of the difficulty of contacting the municipalities and obtaining their data. Sampling data will be taken from the largest governorates in the West Bank, which represent $85 \%$ of the West Bank's population. For each governorate, the central municipality was chosen as a sampling unit. The municipalities are Ramallah, Nablus, Hebron, Jericho, Jenin, Tulkarem, Qalqilia, Salfit, Tubas, Bethlehem, and Al Bireh.

The primary data used for the study were from interviews and questionnaires conducted to analyze the collected data. The interviewees include the LGUs, Ministry of Local Governments, Municipal Development and Lending Fund (MDLF), Palestinian Capital Market Authority (PCMA), and Palestinian Exchange (PEX). Municipalities' financial data and budgets for the last five years (from 2012 till 2017) making up the secondary data.

The variables of this study are related to the municipal bonds, considering these variables with an eye on particular variables in the Palestinian 
environment. The significant variables that have been used, which affect issuing municipal bonds and the capital investments problems, are: macroeconomic variables, status variables (measured by municipality size, outstanding debt and financial distress, financial reporting quality) and municipal bonds issuance variables.

In developing countries, the willingness to issue municipal bonds should be given attention and measured because public confidence in such instruments could be critical for municipalities (Samonikov, Fotov, Gruevski, \&Veselinova, 2016).

Macroeconomic variables measure the economy and market to launch municipal bonds, based on the interest rates and currency fluctuation across years. For the Palestinian National economy, analysis of the general budget, international investment position, and the external debt were analyzed. In other words, the local economy, revenues per capita, expenditures per capita, cost of labor, unemployment rate, in addition to the socioeconomic variables that assess the future investment needs of each municipality.

Status variables measure the financial condition, fiscal health, sustainability of the municipality, which affect the issuance of municipal bonds. The variables that have chosen are municipality size, outstanding debt, financial distress, and financial reporting quality.

Three indicators define municipality size: population, assets owned, and operating activities, which are affected by the ability to generate revenues. The large municipalities should issue bonds because they are capitals of the economy with the highest population density. Large municipalities are centers of economic activity and the basis for investment and financial centers. The population is a common measure for the size of the municipality. The population of sample municipalities was taken into consideration when representing the sample of the central municipality of each governorate in Palestine.

To measure municipality size variable, the current and fixed assets were analyzed vertically as a percentage from total assets. Financial analysis depends on financial numbers available at the financial statements; better analysis will result from better representative financial statements. Operating activities analysis examined the mandatory surplus from the operating budgets, with analysis of the profitable budgets to understand the structure of revenues and expenditures at Palestinian municipalities.

The debt of local governments is usually regulated by law on public debt, followed by a particular regulation on local debt developed to achieve three issues: (a) debt authorization for each type of local government; (b) types of legal instruments such as bonds; and (c) establishment of a debt limit (Catherine, Farvacque, \&Milhaly, 2014). The outstanding debt and financial distress variable summarize the fundamental analysis for each and determines the credit rating suggestion by reviewing the following: 1) the budgets to find if a surplus or deficit occurs, 2) the variance between current and actual balances, 3) the application of liquidity and solvency ratios.

To avoid liquidity problems, local governments should set up a debt service reserve fund to ensure timely repayment of debt.Ten municipalities out of eleven from the study sample had information about their financial position. Not all municipalities filled the required data for the last year in full, other municipalities neither published the information nor answered the researcher such as Tulkarem municipality.

What standards local government units follow: Governmental Accounting Standards (GAS) or

Table 1. Ratios employed in the analysis

Source: Authors.

\begin{tabular}{|c|c|c|c|}
\hline No. & Name & Calculation & Type of ratio \\
\hline 1 & Current ratio & Current assets/current liabilities & Liquidity ratio \\
\hline 2 & Net working capital & Current assets minus current liabilities & Liquidity ratio \\
\hline 3 & Debt to assets & Total liabilities/total assets & Debt ratio \\
\hline 4 & Return on assets & Net income/total assets & Profitability ratio \\
\hline 5 & Change in net assets & Horizontal: time series analysis, which evaluates performance over time & \\
\hline
\end{tabular}


International Public Sector Accounting Standards (IPSAS), and what are the differences and the effects on transparency? These questions would be refined further during the analysis based on the data collection for the reporting quality variable.

These variables represent descriptive variables that are proposed by methods from the research as the best practices and most applicable in Palestine arepar value, maturity,bond type, method of sale, and risk-return relationship.

\section{RESULTS AND DISCUSSION}

The populationis reflected in the macroeconomic variables through per capita ratio is available for municipalities till 2016. Ratios that measure the macroeconomic variables for each municipality:

- unemployment in 2017;

- $\quad$ average expenditure per capita;

- $\quad$ average revenue per capita;

- cost of capital calculated as a percent of administrative and salaries expense from total revenues.

Palestinian municipalities become an important vehicle for absorbing and reduction of the increasing unemployment, which increase their labor expenses (Horizon for Sustainable Development, 2009).One way suggested to absorb unemployment; municipalities may stop the overtime ex- pense of the existing employees and instead bring new workers. Unemployment usually expressed as a percentage rate, with weakness in the labor force employed always associated with higher interest rates. Unemployment is driving governmental units to have more workers under disguised unemployment with low productivity.

The highest unemployment rate is Hebron governorate is $21.7 \%$, while Bethlehem has the highest increase in unemployment rate from 2015 to 2017. Higher unemployment rates may indicate weakness in the economic base and lower credit quality (Palumbo, Shick, \& Zaporowski, 2006).

Capital investments have a high potential of success in Palestine due to one million skilled labor, 95\% literacy rate (higher than MENA region). Competitive labor costs (77\%) lower than Israel, competitive cost of utilities: average utility costs of (\$0.17) per kWh electricity and (\$0.93) per $\mathrm{m} 3$ water. Many sectors have the potential for growth such as agriculture, construction, tourism, IT, and light manufacturing and tourism sector (Palestinian Investment Promotion Agency, 2016).

Low inflation costs: because the Palestinian economy is closely related and connected to the Israeli economy, Palestine has been negatively affected by the high level of inflation in Israel since Paris Protocol agreement. Consumer Price Index (CPI) inflation has been between $2 \%$ and $4 \%$ for the past 5 years (PIPA, 2016). This perpetuated Israel's influence on Palestine limits the PMA's ability to carry out inflation targeting policies.

Table 2. Unemployment in Palestine by governorate

Source: Authors.

\begin{tabular}{|c|c|c|c|}
\hline Growth rate & 2017 & 2015 & Governorate \\
\hline Jenin & $7 \%$ & 17.3 & 16.1 \\
\hline Tubas and northern valleys & $14 \%$ & 20.7 & 18.1 \\
\hline Tulkarem & $-20 \%$ & 14.3 & 17.8 \\
\hline Nablus & $9 \%$ & 18.5 & 17 \\
\hline Qalqilia & $-23 \%$ & 10.1 & 13.2 \\
\hline Salfit & $-1 \%$ & 15.2 & 15.4 \\
\hline Ramallah \& Al-Bireh & $-19 \%$ & 15.9 & 19.7 \\
\hline Jericho \& ILAghwar & $1 \%$ & 14.7 & 14.5 \\
\hline Bethlehem & $45 \%$ & 19.9 & 13.7 \\
\hline Hebron & $11 \%$ & 21.7 & 19.6 \\
\hline West Bank & $3 \%$ & 17.9 & 17.3 \\
\hline Total & $7 \%$ & 27.7 & 25.9 \\
\hline
\end{tabular}


Table 3. International investment position in Palestine

\begin{tabular}{|c|c|c|c|c|c|c|}
\hline \multirow[t]{2}{*}{ Investments stocks by type of investment } & $\begin{array}{c}\text { USD } \\
\text { million }\end{array}$ & Ratios & $\begin{array}{c}\text { USD } \\
\text { million }\end{array}$ & Ratios & $\begin{array}{c}\text { USD } \\
\text { million }\end{array}$ & Ratios \\
\hline & \multicolumn{2}{|c|}{ Total 2012} & \multicolumn{2}{|c|}{ Total 2016} & \multicolumn{2}{|c|}{ Total 2017} \\
\hline International investment position (net) & 532 & $100 \%$ & 1,173 & $100 \%$ & 1,373 & $100 \%$ \\
\hline Total external assets & 5,262 & $100 \%$ & 6,101 & $100 \%$ & 6,405 & $100 \%$ \\
\hline Foreign direct investment abroad & 232 & $4 \%$ & 400 & $7 \%$ & 420 & $7 \%$ \\
\hline Portfolio investments abroad & 1,031 & $20 \%$ & 1,112 & $16 \%$ & 1,052 & $18 \%$ \\
\hline Other investments abroad & 3,336 & $63 \%$ & 4276 & $70 \%$ & 4,538 & $70 \%$ \\
\hline Reserve assets & 663 & $13 \%$ & 313 & $7 \%$ & 445 & $5 \%$ \\
\hline Total foreign liabilities & 4,730 & $100 \%$ & 4,928 & $100 \%$ & 5,082 & $100 \%$ \\
\hline Foreign direct investment in Palestine & 2,337 & $49 \%$ & 2,660 & $53 \%$ & 2,704 & $54 \%$ \\
\hline Foreign portfolio investments in Palestine & 809 & $17 \%$ & 658 & $13 \%$ & 666 & $13 \%$ \\
\hline Foreign other investments in Palestine & 1,585 & $34 \%$ & 1,610 & $34 \%$ & 1,720 & $33 \%$ \\
\hline
\end{tabular}

The results of Palestinian International Investment Position went from USD 532 million in 2012 to USD 1,173 million in 2016 (PCBS, 2016), and reached USD 1,373 million by the end of 2017 (PCBS, 2017) These consist of external assets minus foreign liabilities, meaning that Palestinian economy had invested outside the country by more than the foreign investment. The growth rate in 2017 was $158 \%$ than 2012 as a base year (duplicated 2.5 times), so a priority than to attract Palestinian money to stay serving the economy by new instruments like bonds.

In 2017, the Palestinian economy analysis of other investments revealed that cash deposits of local banks in foreign banks and foreign exchange are the main contributors in the external assets value of USD4,538 million, creating 70\% of external assets. Foreign direct investment abroad reached $7 \%$, while portfolio investments overseas had contributed to $18 \%$ of the total value of external assets. The total stocks of foreign liabilities in Palestine had amounted USD 5,082 million and consist of the foreign direct investment, which contributed $54 \%$ to the foreign liabilities, the second component is portfolio investments about $13 \%$, and the last one is other investments in Palestine, mainly loans and deposits from abroad, which amounted to $33 \%$. The same result by components analysis appeared the investments by Palestinian enterprises outside Palestine are higher than foreign investments in Palestinian enterprises.

The total gross external debt on the Palestinian economy sectors had amounted to USD 1,601 million in 2012 and USD 1,720 million at the end of
2017 (PMA, 2017). The debt owed on government sectors is about $60.5 \%$, while debt owed the banking sector reached $35.1 \%$, and debt on other sectors (non-financial institutions, NGOs....) amounted to be 4.1\%.In 2016,the external debt was USD 1,615 million consisted of USD 1,269 million with a total percentage of 79\%.Long-term debt had been $70 \%$ in 2015 with an apparent indication of what is the trend of monies came to Palestine (PMA, 2016).

Because there is no national currency, there are three currencies that are dealt with in Palestine (Israeli shekels, Jordanian dinars, and US dollars). The interest rate margin between loans and deposits rates is high in Palestine. The interest rate is lower on USD which has a positive impact on the issuance of bonds in dollars.

Palestinian national budget of 2016 resulted in a deficit of USD 1.09 billion, amounted to 8 percent of GDP (World Bank LGPA, 2017). The PNA is under severe fiscal stress, experiencing a significant downturn in budget support from donors, which dropped from 32 percent of GDP in 2008 to 5 percent in 2016 (World Bank LGPA, 2017).

Palestinian national budget of 2016 resulted in a deficit of USD 1.09 billion, amounted to 8 percent of GDP (World Bank LGPA, 2017). The PNA is under severe fiscal stress, experiencing a significant downturn in budget support from donors, which dropped from 32 percent of GDP in 2008 to 5 percent in 2016 (World Bank LGPA, 2017).

Some socio-economic indicators are more important than others. Among these are the state of the 
Table 4. Interest rates on loans and deposits during 2016-2017

Source: Authors.

\begin{tabular}{|c|c|c|c|c|c|c|}
\hline \multirow{2}{*}{ Period } & \multicolumn{2}{|c|}{ NIS } & \multicolumn{2}{|c|}{ USD } & \multicolumn{2}{|c|}{ JD } \\
\hline & Loans & Deposits & Loans & Deposits & Loans & Deposits \\
\hline 2014 & 9.35 & 1.32 & 6.44 & .62 & 7.48 & 2.08 \\
\hline 2014 & 9.09 & 1.46 & 6.05 & .83 & 7.20 & 2.15 \\
\hline 2015 & 7.80 & 1.56 & 5.92 & .94 & 6.94 & 2.20 \\
\hline 2016 & 6.94 & 1.49 & 5.87 & 1.01 & 6.34 & 2.28 \\
\hline 2016 & 7.09 & 1.43 & 5.79 & 1.32 & 6.61 & 2.29 \\
\hline
\end{tabular}

Table 5. Comparison of Palestinian national budget

Source: Authors.

\begin{tabular}{l|c|c|c}
\hline \multicolumn{1}{c|}{ (MoFP, 2017) } & \multicolumn{2}{|c|}{$\mathbf{2 0 1 8}$} & $\mathbf{2 0 1 7}$ \\
\hline General PNA budget in thousands & - & $16,559,061$ & $16,290,604$ \\
Infrastructure sector & $4 \%$ & 583,484 & $4 \%$ \\
\hdashline Among infrastructure: MoLG & $0.9 \%$ & 139,176 & $1.3 \%$ \\
Ministry of Health & $11.0 \%$ & $1,787,683$ & $10.6 \%$ \\
Ministry of Higher Education & $20.6 \%$ & $3,350,781$ & $1,724,572$ \\
\hline
\end{tabular}

economy and population level. Population variable had taken the attention of municipal analysts (Palumbo, Shick, \& Zaporowski, 2006). Increasing per capita expenditures reflect changes in expenditures relative to changes in population. An increase in per capita expenditures could indicate that the cost of providing services exceeds the ability of residents to pay.

Different ratios and analysis tools have been used to measure status variables and municipal bonds issuance variables, such as mandatory surplus operating budget, average collection rate of accounts receivable, average change in net assets, current ratio, debt to assets, return on assets, net lending, net working capital, average change of net income, average total revenues/total expenditures, collection rate of accounts receivables.
Status variables have subgroup variables: municipality size, outstanding debt and financial distress, financial reporting quality.

The populationhas expressed a size of measure, and for assets owned, a vertical analysis of land rate from total assets was performed. Also, activities of each local government, both the operating and profitable divisions, are analyzed.

According to the results shown in Table 6, net income growth is not stable for municipalities. There is a huge gap between each year's values, the highest average of net income growth is for Bethlehem municipality, and the lowest value is Tubas municipality.

According to the results in Table 7, some municipalities had a deficit in profitable business enter-

Table 6. Net income growth rates (\%) for the period 2014-2017

Source: Authors.

\begin{tabular}{|c|c|c|c|c|c|}
\hline Municipality & 2014 & 2015 & 2016 & 2017 & Average change \\
\hline Tubas & -2762 & -27 & -88 & 1467 & $-352 \%$ \\
\hline Salfit & -66 & 15 & 23 & 7 & $-5 \%$ \\
\hline Qalqilia & -61 & -69 & 78 & -219 & $-68 \%$ \\
\hline Nablus & -190 & -125 & -371 & -25 & $-178 \%$ \\
\hline Ramallah & -35 & -924 & 4 & - & $-318 \%$ \\
\hline Hebron & 8 & -62 & -53 & - & $-36 \%$ \\
\hline Bethlehem & 40 & -9 & 18 & - & $16 \%$ \\
\hline Al Bireh & -53 & 2569 & 45 & - & -859 \\
\hline Jenin & 62 & 22 & -44 & - & $13 \%$ \\
\hline Jericho & - & - & -209 & - & $-209 \%$ \\
\hline
\end{tabular}


Table 7. Revenues and expenditures analysis

\begin{tabular}{|c|c|c|c|c|c|c|c|}
\hline Municipality & Year & $\begin{array}{c}\text { Total } \\
\text { revenues }\end{array}$ & $\begin{array}{l}\text { Revenues } \\
\text { growth rate }\end{array}$ & $\begin{array}{c}\text { Total } \\
\text { expenditures }\end{array}$ & $\begin{array}{l}\text { Expenditures } \\
\text { growth rate }\end{array}$ & Surplus/deficit & $\begin{array}{c}\text { Total } \\
\text { revenues/total } \\
\text { expenditures }\end{array}$ \\
\hline \multirow{3}{*}{ Tubas } & 2015 & $6,142,069$ & - & $3,919,237$ & - & $2,222,832$ & 1.57 \\
\hline & 2016 & $5,103,837$ & $-17 \%$ & $5,113,619$ & $30 \%$ & $(9,782)$ & 1.00 \\
\hline & 2017 & $6,956,008$ & $36 \%$ & $5,696,195$ & $11 \%$ & $1,259,813$ & 1.22 \\
\hline \multirow{3}{*}{ Tulkarem } & 2015 & $73,288,131$ & - & $74,616,187$ & - & $(1,328,056)$ & 0.98 \\
\hline & 2016 & $69,833,428$ & $-5 \%$ & $69,216,774$ & $-7 \%$ & 616,654 & 1.01 \\
\hline & 2017 & $82,368,002$ & $18 \%$ & $540,515,688$ & $681 \%$ & $(458,147,686)$ & 0.15 \\
\hline \multirow{3}{*}{ Jericho } & 2015 & $27,671,104$ & - & $21,770,801$ & - & $5,900,303$ & 1.27 \\
\hline & 2016 & $20,689,282$ & $-25 \%$ & $22,762,574$ & $5 \%$ & $(2,073,292)$ & 0.91 \\
\hline & 2017 & $21,932,086$ & $6 \%$ & $1,367,254$ & $-94 \%$ & $20,564,832$ & 16.04 \\
\hline \multirow{3}{*}{ Al Bireh } & 2015 & $45,979,268$ & - & $14,901,438$ & - & $31,077,830$ & 3.09 \\
\hline & 2016 & $39,107,291$ & $-15 \%$ & $28,309,135$ & $90 \%$ & $10,798,156$ & 1.38 \\
\hline & 2017 & $33,989,618$ & $-13 \%$ & $27,279,191$ & $-4 \%$ & $6,710,427$ & 1.25 \\
\hline \multirow{3}{*}{ Hebron } & 2015 & $77,075,813$ & - & $62,020,238$ & - & $15,055,575$ & 1.24 \\
\hline & 2016 & $75,252,031$ & $-4 \%$ & $49,032,573$ & $-21 \%$ & $25,219,458$ & 1.51 \\
\hline & 2017 & - & $-100 \%$ & - & $-100 \%$ & - & - \\
\hline \multirow{3}{*}{ Jenin } & 2015 & $21,175,905$ & - & $7,708,127$ & - & $13,467,778$ & 2.75 \\
\hline & 2016 & $17,783,973$ & $-16 \%$ & $11,713,729$ & $52 \%$ & $6,070,244$ & 1.52 \\
\hline & 2017 & - & $-100 \%$ & - & $-100 \%$ & - & - \\
\hline \multirow{3}{*}{ Bethlehem } & 2015 & - & - & - & - & - & \\
\hline & 2016 & $17,048,242$ & - & $12,515,145$ & - & $4,533,097$ & 1.36 \\
\hline & 2017 & $20,721,097$ & $22 \%$ & $8,574,389$ & $-31 \%$ & $12,146,708$ & 2.42 \\
\hline \multirow{3}{*}{ Ramallah } & 2015 & - & - & - & - & - & - \\
\hline & 2016 & $61,245,669$ & - & $32,117,279$ & - & $29,128,390$ & 1.91 \\
\hline & 2017 & $72,554,235$ & $18 \%$ & $46,745,729$ & $46 \%$ & $25,808,506$ & 1.55 \\
\hline \multirow{3}{*}{ Salfit } & 2015 & $15,672,065$ & & $13,069,780$ & & $2,602,285$ & 1.20 \\
\hline & 2016 & $17,102,780$ & $9 \%$ & $13,966,898$ & $7 \%$ & $3,135,882$ & 1.22 \\
\hline & 2017 & $19,367,249$ & $13 \%$ & $13,745,042$ & $-2 \%$ & $5,622,207$ & 1.41 \\
\hline \multirow{3}{*}{ Qalqilia } & 2015 & $68,378,617$ & - & $67,210,912$ & - & $1,167,705$ & 1.02 \\
\hline & 2016 & $68,636,455$ & $0 \%$ & $75,138,181$ & $12 \%$ & $(6,501,726)$ & 0.91 \\
\hline & 2017 & $79,923,548$ & $16 \%$ & $50,133,226$ & $-33 \%$ & $29,790,322$ & 1.59 \\
\hline \multirow{3}{*}{ Nablus } & 2015 & $128,031,661$ & - & $110,920,779$ & - & $17,110,882$ & 1.15 \\
\hline & 2016 & $98,750,417$ & $-23 \%$ & $124,653,319$ & $12 \%$ & $(25,902,902)$ & 0.79 \\
\hline & 2017 & $108,101,417$ & $9 \%$ & $127,538,056$ & $2 \%$ & $(19,436,639)$ & 0.85 \\
\hline & & $1,398,881,298$ & - & $1,642,271,493$ & $1188 \%$ & $(243,390,195)$ & 0.85 \\
\hline
\end{tabular}

prises, reasoning this deficit to collection rates, unproductive expenses, weak financial management, and hidden or disguised unemployment, also called "labor hoarding" Further analysis of the type of business budget is shown.

Cross-sectional analysis benchmarking: in relation to other firms in the industry, the ones who are better than average. For the following ratios, sample municipalities formed the benchmark that can be used for LGUs in Palestine.

Six municipalities from the sample participated in this benchmark. Extreme ratio results associated with the most populated municipalities. Further details of these cross-sectional ratios are given in Table 9.

Table 8. Ratios benchmark of Palestine

Source: Authors.

\begin{tabular}{lc|c}
\hline & Ratio & Result \\
\hline Change in net assets & $21 \%$ \\
\hline Current ratio & & 2.49 \\
Debt to assets & & \\
\hline Return on assets & & $0.03 \%$ \\
\hline
\end{tabular}


Table 9. The highest and lowest values of the ratios

Source: Authors.

\begin{tabular}{|c|c|c|c|c|c|c|c|}
\hline Ratio & Result & Highest value & Municipality & Year & Lowest value & Municipality & Year \\
\hline Change in net assets & $21 \%$ & $596 \%$ & Salfit & 2015 & $-86 \%$ & Hebron & 2016 \\
\hline Current ratio & 2.49 & 9.27 & Al Bireh & 2014 & 0.40 & Hebron & 2015 \\
\hline Debt to assets & $21 \%$ & $92 \%$ & Hebron & 2017 & $1 \%$ & Al Bireh & 2014 \\
\hline Return on assets & $0.03 \%$ & $8 \%$ & Ramallah & 2015 & $-5 \%$ & Hebron & 2015 \\
\hline
\end{tabular}

Many financial ratios are used and analysis of the average of growth for others, each affects the issuance of municipal bonds in a different way: mandatory surplus operating budget, average collection rate of accounts receivable, average change in net assets, current ratio, debt to assets, return on assets, net lending, net working capital, average change of net income, average total revenues/total expenditures, collection rate of accounts receivables.

Disclosure Index for the last five years (2013-2017) on websites, LGUs quality of disclosure is low, average disclosure for our sample municipalities is $50 \%$.

Table 10. Disclosure index of sample municipalities

\begin{tabular}{|c|c|c|}
\hline No. & Municipality & Out of $100 \%$ \\
\hline 1 & Al Bireh & 0 \\
\hline 2 & Qalqilia & 0 \\
\hline 3 & Tulkarem & 0 \\
\hline 4 & Jenin & 0 \\
\hline 5 & Hebron & 20 \\
\hline 6 & Jericho & 20 \\
\hline 7 & Nablus & 40 \\
\hline 8 & Salfit & 40 \\
\hline 9 & Tubas & 60 \\
\hline 10 & Ramallah & 75 \\
\hline 11 & Bethlehem & 80 \\
\hline \multicolumn{2}{|r|}{ Average } & $31 \%$ \\
\hline
\end{tabular}

Furthermore, the requirements of accrual basis by IPSAS are presented in Table 11.

Table 11. Requirements of accrual basis by IPSAS

Source: Authors.

\begin{tabular}{r:l}
\hline & \multicolumn{1}{|c}{ Requirements of Accrual Basis by IPSAS } \\
\hline a. & A statement of financial position \\
\hline b. & A statement of financial performance \\
\hline c. & A statement of changes in net assets/equity \\
\hdashline d. & A cash flow statement \\
\hline
\end{tabular}

The result of the municipality's variable by disclosure of financial statements on their websites for the last five years is shown in Table 12.
Table 12. Disclosure of financial statements

Source: Authors

\begin{tabular}{c:c}
\hline Group one & No disclosure of any financial statement \\
\hline 1 & Al Bireh municipality \\
\hdashline 2 & Qalqilia municipality \\
\hdashline 3 & Tulkarem municipality \\
\hdashline 4 & Jenin municipality \\
\hline
\end{tabular}

Table 13 shows to what extent municipalities follow the requirement of cash basis by IPSAS is the statement of cash receipts and payments.

Table 13. Statement of cash receipts and payments

Source: Authors

\begin{tabular}{c|c|c|c|c|c|c}
\hline $\begin{array}{c}\text { Group } \\
\text { two }\end{array}$ & $\begin{array}{c}\text { Statement of } \\
\text { cash receipts and } \\
\text { payments }\end{array}$ & $\mathbf{2 0 1 3}$ & $\mathbf{2 0 1 4}$ & $\mathbf{2 0 1 5}$ & $\mathbf{2 0 1 6}$ & $\mathbf{2 0 1 7}$ \\
\hline 5 & Bethlehem municipality & Yes & Yes & Yes & Yes & No \\
\hline 6 & Jericho municipality & No & No & No & Yes & No \\
\hline 7 & Nablus municipality & No & No & Yes & Yes & No \\
\hline
\end{tabular}

After presenting the different variables, issuance guidelines based on subgroup variables, and financial analysis ratios, Table 11 shows the requirements of accrual basis by IPSAS.

After examining the municipality's financial statements according to the accrual basis by IPSAS, it has been found the following results as shown in Table 14.

Table 15 shows the final analysis to test the research hypotheses.

Based on the previous analysis, macroeconomic variables and municipality status affect the issuance of municipal revenue bonds, which are targeted to finance capital investments of local government units in Palestine.Macroeconomic variables measured by revenues and expenditures per capita, cost of capital, and unemployment affect the issuance of municipal bonds. 
Table 14. Municipality's financial statements according to the accrual basis by IPSAS

\begin{tabular}{|c|c|c|c|c|c|c|c|}
\hline Group three & Municipality & St. & 2013 & 2014 & 2015 & 2016 & 2017 \\
\hline \multirow{4}{*}{8} & \multirow{4}{*}{$\begin{array}{l}\text { Ramallah } \\
\text { municipality }\end{array}$} & a. & Yes & Yes, without notes & Yes, without notes & Yes, without notes & No \\
\hline & & b. & Yes & Yes, without notes & Yes, without notes & Yes, without notes & No \\
\hline & & c. & No & Yes, without notes & Yes, without notes & Yes, without notes & No \\
\hline & & d. & Yes & Yes, without notes & Yes, without notes & Yes, without notes & No \\
\hline \multirow{4}{*}{9} & \multirow{4}{*}{$\begin{array}{l}\text { Tubas } \\
\text { municipality }\end{array}$} & a. & No & Yes & Yes & Yes & No \\
\hline & & b. & No & Yes & Yes & Yes & No \\
\hline & & c. & No & Yes & Yes & Yes & No \\
\hline & & d. & No & Yes & Yes & Yes & No \\
\hline \multirow{4}{*}{10} & \multirow{4}{*}{$\begin{array}{l}\text { Salfit } \\
\text { municipality }\end{array}$} & a. & Yes & Yes, without notes & No & No & No \\
\hline & & b. & Yes & Yes, without notes & No & No & No \\
\hline & & c. & Yes & Yes, without notes & No & No & No \\
\hline & & d. & Yes & Yes, without notes & No & No & No \\
\hline \multirow{4}{*}{11} & \multirow{4}{*}{$\begin{array}{l}\text { Hebron } \\
\text { municipality }\end{array}$} & a. & No & No & No & Yes, draft & No \\
\hline & & b. & No & No & No & Yes, draft & No \\
\hline & & c. & No & No & No & Yes, draft & No \\
\hline & & d. & Mo & No & No & Yes, draft & No \\
\hline
\end{tabular}

Table 15. Final analysis of macroeconomic and status variables

\begin{tabular}{|c|c|c|c|c|c|c|c|c|c|c|c|c|c|c|c|c|c|c|}
\hline \multirow{2}{*}{$\begin{array}{c}\text { Final } \\
\text { Municipality }\end{array}$} & \multicolumn{4}{|c|}{$\begin{array}{c}\text { 1. Macroeconomic } \\
\text { variables }\end{array}$} & \multicolumn{12}{|c|}{ 2. Status variables } & \multicolumn{2}{|c|}{$\begin{array}{c}\text { Result } \\
\text { Rejected, } \\
\text { R for the } \\
\text { hypothesis }\end{array}$} \\
\hline & 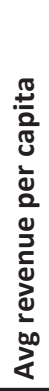 & 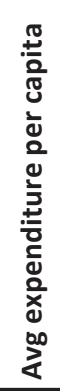 & 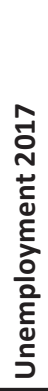 & 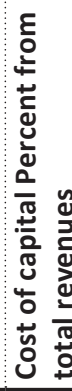 & 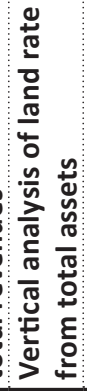 & 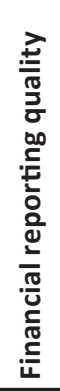 & 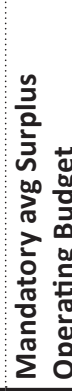 & 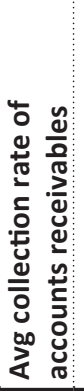 & 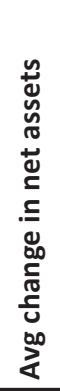 & 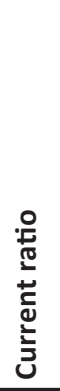 & 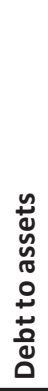 & 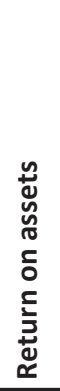 & 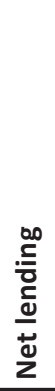 & 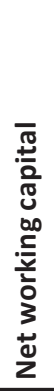 & 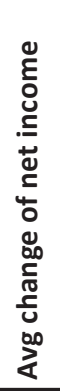 & 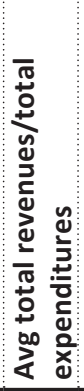 & 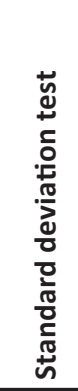 & 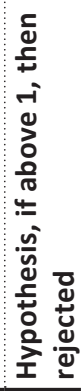 \\
\hline Hebron & 10 & 9 & 1 & 6 & 4 & 5 & 7 & 7 & 6 & 7 & 7 & 6 & 7 & 8 & 4 & 6 & 2 & $\mathrm{R}$ \\
\hline Nablus & 7 & 6 & 4 & 10 & 7 & 4 & 2 & 3 & 4 & 2 & 6 & 4 & 1 & 1 & 6 & 10 & 3 & $\mathrm{R}$ \\
\hline Tulkarem & 4 & 3 & 9 & 9 & & 6 & 11 & & & & & & & & & 11 & 3 & $\mathrm{R}$ \\
\hline Qalqilia & 3 & 1 & 10 & 11 & 1 & 6 & 10 & 2 & 4 & 6 & 5 & 5 & 6 & 7 & 5 & 9 & 3 & $\mathrm{R}$ \\
\hline Al Bireh & 6 & 7 & 6 & 2 & 3 & 6 & 3 & 4 & 5 & 1 & 1 & 3 & 2 & 2 & 10 & 3 & 2 & $\mathrm{R}$ \\
\hline Jenin & 9 & 11 & 5 & 8 & 10 & 6 & 4 & & & & & & & & 2 & 2 & 3 & $\mathrm{R}$ \\
\hline Ramallah & 1 & 5 & 6 & 4 & 2 & 2 & 1 & 7 & 2 & 5 & 3 & 2 & 3 & 5 & 8 & 5 & 2 & $\mathrm{R}$ \\
\hline Bethlehem & 8 & 8 & 3 & 7 & 9 & 1 & 5 & 5 & & 6 & & & & 6 & 1 & 4 & 3 & $\mathrm{R}$ \\
\hline Jericho & 5 & 4 & 8 & 3 & 8 & 5 & 6 & 8 & & & & & & & 7 & 1 & 2 & $R$ \\
\hline Tubas & 11 & 10 & 2 & 1 & 6 & 3 & 9 & 1 & 3 & 4 & 2 & 1 & 5 & 4 & 9 & 8 & 3 & $\mathrm{R}$ \\
\hline Salfit & 2 & 2 & 7 & 5 & 5 & 4 & 8 & 6 & 1 & 3 & 4 & 1 & 4 & 3 & 3 & 7 & 2 & $R$ \\
\hline
\end{tabular}

Therefore, hypothesis 1 can be accepted.

Municipal status variables affect the issuance of municipal bonds, which has subgroup variables of municipality size, financial reporting quality, outstanding debt, and financial distress.

Therefore, hypothesis 2 can be accepted. 


\section{CONCLUSION}

The debate about the financing of municipal projects is shifting from grants dependence to a more proper discussion of the new financial instruments, specifically municipal bonds, and the revenue bonds type. Municipal revenues bonds can solve the financing obstacle for development projects of the local government units in Palestine. Based on an analysis of the debt to assets ratio, all Palestinian municipalities have a small amount of debt (less than 1), so there is an area of getting benefit from some debts.

To issue municipal bonds, local government revenues and creditworthiness should significantly be improved, the same result by Vazquez in 2015. Results are consistent with the golden rule of Vazquez, which condition the use of bonds proceeds not for current expenditures but new development investments. No issuance until achieving some surplus from the operating budget, some municipalities had a surplus in 2017, but the average with 2016 deficit resulted in deficit, so improvement could be taken in mind based on the last year.

If municipalities are considered bad service delivery, the new strategy should be implemented to prevent them from becoming worse. The most critical task is the development of legal framework for the issuance of municipal bonds. Moreover, the establishment of a debt limit. Financial information could be misleading if not provided adequately and based on accounting standards. Municipalities could not have any financing without a clear and solid base of assets and operating revenues

The most suitable bonds issuers are Hebron, Qalqilia, Tubas, and Salfit municipalities. For each municipality, a project was chosen. Qalqilia municipality did not disclose its strategic plans. Hebron is seeking financing of USD 5 million for the establishment of parking lots and complexes for public vehicles (SDIP 2016-2019). Salfit is seeking financing of USD 5 million for the creation of a recreational city (SDIP 2013-2016). Tubas is seeking financing of USD 1 million for the drilling and equipping agricultural water well in the Tubas plain area (SDIP 2014).

According to the research results, municipal bonds are highly recommended. The allowed debit limits need to be set, and special instructions may be added to the legal framework.

MoLG should be the data centres for all municipalities. Budget gate needs to be improved to provide better data for their owners MoLG and to help them in their goals of the best monitoring of LGUs. MoLG role is beyond giving approvals to municipalities on loans and line credit and other bank facilities, interest rates need to be scrutinized.

Instructions from MoLG need to be established and declared about the date of audited financial statements publishing, at least before June of the next fiscal year. Corporations should complete them before the end of April of the next year.

Further researches on LGUs in Palestine can be conducted about the compliance of LGUs with IPSAS of the cash basis.

\section{REFERENCES}

1. Adelino, M., Cunha, I., \& Ferreira, M. (2017). The economic effects of Public Financing: Evidence from municipal bond ratings recalibration. Review of Financial Studies, 9(1), 3223-3268. https:// doi.org/10.1093/rfs/hhx049
2. Angkinand, A., Barth, Jr. R., Phumiwasana, T., \& Wihlborg, C. (2006). Regulatory and market forces in controlling bank risktaking: a cross-country analysis. AIB Southeast Asia Regional Conference. Bangkok, Thailand.
3. ARIJ (2009). Idhna town profile. Applied Research Institute Jerusalem (ARIJ). Village Profile Project. Retrieved from http:// vprofile.arij.org/hebron/pdfs/ Idhna.pdf 
4. Bajo, A., \& Primorac, M. (2010). Local government borrowing practice in Croatia. Financial Theory and Practice, 34(4), 379406. Retrieved from http://www ijf.hr/eng/FTP/2010/4/bajo-primorac.pdf

5. Benson, E. D., Kidwell, D. S.,Koch, T. W., \& Rogowski,R. J. (1981). Systematic Variation in Yield Spread for Tax-Exempt General Obligation Bonds. Journal of Financial and Quantitative Analysis, 16(5), 475-485. https:// doi.org/10.2307/2331055

6. BMA Management Consulting Inc. (2016). Financial Indicators Analysis. Retrieved from https:// www.stratfordcanada.ca/en/insidecityhall/resources/Finance/ Finance_Reports/2017-BMAMunicipal-Study.pdf.

7. Capeci, J. (1991). Credit Risk, Credit Ratings, and Municipal Bond Yields: A Panel Study. National Tax Journal, 44(4), 4156. Retrieved from https://www. jstor.org/stable/pdf/41788921. pdf?seq $=1$

8. Catherine, D., Farvacque, V., \& Milhaly, M. (2014). Municipal Finances: A Handbook for local governments. Washington, DC: World Bank. https://doi. org/10.1596/978-0-8213-9830-2

9. Daniels, K., \& Vijayakumar, J. (2007). Does underwriter reputation matter in the municipal bond market? Journal of Economics and Business, 59, 500-519. https://doi.org/10.1016/j. jeconbus.2006.09.002

10. Gitman, L. J., \& Zutter, C. (2012). Principles of Managerial Finance (13th ed). Prentice Hall. Retrieved from http://ledgys.io/principles_ of_managerial_finance_13th_edition_gitman_pdf.pdf

11. Harris, L.E., \& Piwowar, M.S. (2004). Municipal bond liquidity (Working paper). Securities and Exchange Commission. Retrieved from https://pdfs.semanticscholar. org/ab47/5928649c86b545ef5ba32 a5d3777eff0c28f.pdf

12. Horizon for Sustainable Development (2009). Update of Diagnostic Report for the
Local Governance System in the Occupied Palestinian territory, Part 1. United Nations Development Programme of Assistance to the Palestinian People (UNDP/PAPP) (pp. 1630). Retrieved from https://www. ps.undp.org/content/dam/papp/ docs/Publications/UNDP-pappresearch-undaf_2018-2022.pdf

13. Kablan, A. (2013). Financial statement analysis in municipalities and an application. International Journal of Research in Business and Social Science, 2(3), 75-86. https://doi.org/10.20525/ ijrbs.v2i3.76

14. Kiewiet, R., \& Szalaky, K. (1996). Constitutional limitations on borrowing: An analysis of state bonded indebtedness. Journal of Law, Economics and Organization, 12(1), 62-97. https://doi. org/10.1093/oxfordjournals.jleo. a023362

15. Liu, S. X., Wang,J., \& Wu, C. (2003). Effects of credit quality on the relation between tax-exempt and taxable yields. Journal of Fixed Income, 13, 80-99. https://doi. org/10.3905/jfi.2003.319355

16. Palestinian Monetary Authority (2017). Financial Stability Report Retrieved from http://www.pma. ps/Portals/1/Users/002/02/2/ Publications/English/Annual\%20 Reports/Financial\%20Stability\%20 Reports/Financial\%20Stability\%20 2017.pdf

17. Palumbo, G., Shick, R., \& Zaporowski, M. (2006). Factors affecting A municipality's bond rating: An empirical study. Journal of Business \& Economics Research, 4(11), 37-42. https://doi. org/10.19030/jber.v4i11.2712

18. PCBS (2012). Localities in the Hebron governorate by type of locality and population estimates 2007-2016. Retrieved from http:// www.pcbs.gov.ps/Portals/_Rainbow/Documents/hebrn.htm

19. Ramazanov, A., \& Grigorian, K. (2015). Municipal loans as a tool for solving the financial problems of the territory. Procedia Economics and Finance, 2(4), 537-542. https://doi.org/10.1016/ S2212-5671(15)00627-9
20. Sabri, N. (2003). Analysis of Source for Financing the Palestinian Private sector. Arabic Journal for Administration, 23(1). Retrieved from https:// www.mas.ps/download. php?id=8a9c3y567747YY8a9c3

21. Samonikov, M., Fotov, R., Gruevski, I., \& Veselinova, E. (2016). Readiness of municipalities in the developing countries for issue of municipal bonds through the analysis of their budget accounts (overview of the municipality of Stip R.Macedonia). International Journal of Management and Applied Science, 2(8), 44-47. Retrieved from http://ijmas. iraj.in/paper_detail.php?paper_ $\mathrm{id}=5466 \&$ name $=$ Readiness_of_ Municipalities_in_the_Developing_Countries_For_Issue_of_Municipal_Bonds_Through_the_ Analysis_of_Their_Budget_Accounts_(Overview_of_the_Municipality_of_Stip_-_R._Macedonia)

22. Sawafta, N. M. (2011). The readiness of municipalities $(A, B)$ in the west bank to administering the responsibility of the property tax and licensed professions. AnNajah National University, Faculty of Graduate Studies. Retrieved from https://repository.najah.edu/ handle/20.500.11888/6315

23. Schulz, A., \& Wolff, G. (2016). The German Sub-National Government Bond Market: Structure, Determinants of Yield Spreads and Berlin's Forgone Bail-out. Journal of Economics and Statistics, 221(1). https://doi. org/10.1515/jbnst-2009-0105

24. Simonsen, B., Robbins, M.D., \& Helgerson, L. (2001). The Influence of Jurisdiction, Size and Sale Type on Municipal Bond Interest Rates: An Empirical Analysis. Public Administration Review, 61(6),709-717. https://doi. org/10.1111/0033-3352.00141

25. World Bank (2017). The performance of Palestinian local governments. Retrieved from http://pubdocs.worldbank.org/ en/645051511806498601/LGPA presentation-Nov-13-2018-English.pdf 